\title{
The Use of E-Mind Map in Online Think-Pair-Share-Based Reading Learning on Students' Reading Comprehension
}

\author{
N.N. Hardiyanti ${ }^{*}$, I.P.N.W. Myartawan ${ }^{2 *}$, I.N.P. Hadisaputra ${ }^{3 *}$ (i)
}

1,2,3 English Language Ganesha University of Education, Bali, Indonesia

\section{A R T I CL E I N F O}

Article history:

Received February 15, 202

Revised February 17, 2021

Accepted June 17, 2021

Available online August 25, 2021

Kata Kunci:

E-Peta Pikiran, Think Pair

Share, Pemahaman

Membaca, Online

Keywords:

E-Mind Map, Think Pair

Share, Reading

Comprehension, Online

DOI:

http://dx.doi.org/10.23887/jpbi.v9

$\underline{\mathrm{i} 2.32196}$

\begin{abstract}
A B S T R A K
Masih banyak siswa yang tidak menyukai kegiatan membaca. Hal ini dikarenakan siswa merasa bahwa membaca adalah kegiatan yang melelahkan, sehingga siswa jarang memiliki niat untuk membaca. Siswa merasa bosan ketika membaca dan membuat siswa cepat. Inilah alasan utama mengapa siswa tidak suka membaca. Penelitian ini bertujuan untuk menganalisis keefektifan penggunaan e-mind map dalam pembelajaran membaca online berbasis Think-Pair-Share terhadap pemahaman membaca siswa EFL Indonesia. Penelitian ini merupakan penelitian pra-eksperimen dengan desain one-group pretest-posttest design. Sampel terdiri dari 32 siswa kelas. Teknik yang digunakan untuk mengumpulkan data yaitu observasi, dan wawancara. Data dikumpulkan melalui pretest dan posttest dan dianalisis menggunakan statistik deskriptif dan inferensial berbantuan SPSS versi 24. Hasil penelitian menunjukkan bahwa rata-rata nilai posttest siswa adalah 91,13 yang lebih tinggi dari rata-rata pretest siswa skor yaitu 75,72 dan terdapat perbedaan yang signifikan antara rerata skor pretes dan skor postes (Sig. (dua sisi) adalah $.000<.05$ ). Oleh karena itu, dapat disimpulkan bahwa e-mind map dalam pembelajaran membaca online berbasis Think-Pair-Share berpengaruh positif dan signifikan terhadap pemahaman membaca siswa EFL Indonesia. Implikasi penelitian yaitu guru dapat menggunakan integrasi peta e-mind dalam pengaturan Think-Pair-Share online. Penerapan e-mind dalam pengaturan Think-Pair-Share online dapat memudahkan siswa dalam belajar dan membuat suasana belajar menyenangkan sehingga dapat meningkatkan pemahaman membaca siswa, terutama pada keterampilan belajar bahasa Inggris seperti berbicara,
\end{abstract} mendengarkan, dan menulis.

\section{A B S T RA C T}

There are still many students who do not like reading. Students feel that reading is a tiring activity, so students rarely have the intention to read. Students feel bored when reading and make students fast. This is the main reason why students do not like to read. This study aims to analyse the effectiveness of using e-mind maps in online reading learning based on ThinkPair-Share on the reading comprehension of Indonesian EFL students. This research is a pre-experimental study with a onegroup pretest-posttest design. The sample consists of 32 class students. The techniques used to collect data are observation and interviews. Data were collected through pretest and posttest and analysed using descriptive and inferential statistics assisted by SPSS version 24. The results showed that the average posttest score of students was 91.13, which was higher than the average student pretest score of 75.72, and there were significant differences. The important difference between the mean pretest and posttest scores (Sig. (two-sided) was .000 <.05). Therefore, it can be said that the e-mind map in online reading learning based on Think-Pair-Share has a positive and significant effect on the reading comprehension of Indonesian EFL students. The research implication is that teachers can use e-mind map integration in online Think-Pair-Share settings. The application of e-mind in online Think-Pair-Share settings can facilitate students in learning and create a pleasant learning atmosphere so as to improve students' reading comprehension, especially in learning English skills such as speaking, listening, and writing.

This is an open access article under the CC BY-SA license. Copyright (C) 2021 by Author. Published by Universitas Pendidikan Ganesha.

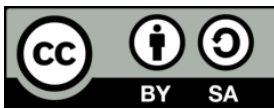

\section{INTRODUCTION}

Reading is one of the essential skills that EFL students should master in learning the target language (Hwang et al., 2020; Knoop-van Campen et al., 2020). It is regarded as the basis of all language skills because it evolves other skills in learning English, such as speaking, listening, and writing (Kamelia, 2019; Shaalan, 2019). In teaching reading to EFL students, comprehension is an essential aspect of reading that should be prioritised. Reading comprehension is the ability to understand the written information, such as words, sentences, and the whole text, to create a mental representation (Fernández-Gutiérrez et al., 2020; YalÇintaŞ Sezgin \& Ulus, 2017). It is an active skill to construct the meaning of the written text in the target language through relating the written 
information with students' background knowledge. Reading comprehension is beneficial in promoting students' language learning since it trains them to process and understand the information in the target language (Fathiara et al., 2019; Shastina et al., 2020). Therefore, fostering EFL students' reading comprehension is worth noted in teaching the target language.

However, the current problem is that many children still do not like reading activities (Anggraeni et al., 2021; Antara \& Aditya, 2019; Windrawati et al., 2020). This is because students feel that reading is a tiresome activity so that students rarely have the intention to read (Cici Marantika, 2019; Widyaningrum \& Hasanudin, 2019). There are still many children who do not understand the benefits of reading. In addition, students also feel that reading has no benefits, so students often experience it (Pramesti, 2018; Widyowati et al., 2020). This problem was also found in one high school. Based on the results of observations made at SMA Negeri 1 Singaraja. The problem found is that there are still many students who do not like to read. Based on interviews conducted by students, it was found that students feel bored when reading and make students fast. This is the main reason why students do not like to read. This will have an impact on students' common knowledge.

Teachers must determine appropriate reading teaching strategies to increase students' interest in learning. In this regard, there are several characteristics of innovative teaching strategies: collaboration (Farsani et al., 2021; Troussas et al., 2020). The use of collaboration is essential for engaging EFL students in learning reading. Hence, several teaching strategies that employ collaboration are crucial to be applied and investigated to find out their effect on students' reading comprehension, especially in the EFL context (Dashtestani, 2013; Raynesa Noor Emiliasari, 2019). In this regard, cooperative learning is one teaching strategy that employs collaboration (Foldnes, 2016; Yati \& Amini, 2020). The utilisation of collaboration in cooperative learning could create meaningful learning and develop EFL students' language learning. Several studies have investigated cooperative strategies based on cooperating learning for teaching reading, such as Think-Pair-Share, TeamsGames-Tournament, Jigsaw, etc (Liebech-Lien, 2021; Rabgay, 2018).

Among these cooperative strategies, Think-Pair-Share is flexible to be applied for teaching in any content of areas or different grade levels (Kurniawan et al., 2018; Wulandari, Abadi, \& Ganing, 2018). More specifically, some studies have investigated the implementation of Think-Pair-Share for teaching reading in the EFL context (Dwigustini \& Widiya, 2020; Shih \& Reynols, 2015). In general, these studies have proven that Think-Pair-Share is an effective strategy for teaching reading comprehension in the EFL context. Considering the flexibility and the effectiveness of Think-Pair-Share in teaching reading for EFL students, the present study uses Think-Pair-Share as an innovative teaching strategy.

Additionally, this research was carried out amidst the global pandemic, where all teaching-learning activities in Indonesian schools were conducted in an online learning mode (Ayuni et al., 2021; Hanik, 2020). English Language teaching can utilise a number of online platforms or Learning Management Systems (LMS) (Zabolotniaia et al., 2020; Zhang et al., 2020). In this research, Think-Pair-Share-based reading instruction would be implemented in an online learning setting assisted with Google Classroom to teach EFL reading. Google Classroom is a suitable LMS for teaching reading because it can help students comprehend the reading text easier since it has great features (Al-Maroof \& Al-Emran, 2018; Santosa et al., 2020).

These features, such as stream, classwork, people, grades, reuse posts, and others, help the students and teachers to discuss any topic about the learning material, maximise collaboration among the students, submitting assignments efficiently, and assisting the teachers in grading students' assignments (Albashtawi \& Al Bataineh, 2020; Mahitsa \& Mahardini, 2020). The effectiveness of Google Classroom in teaching reading and the possibility of doing the discussions and collaboration became the reason to choose Google Classroom as an LMS in implementing Think-Pair-Shar-based reading instruction for teaching EFL reading (Ali \& Maksum, 2020; Guswara, 2020). Therefore, online Think-Pair-Share-based reading instruction setting would be investigated to discover its effect on EFL students reading comprehension.

In addition, the flexible nature of Think-Pair-Share indicates that it enables the integration of mind map into think and pair steps of Think-Pair-Share (Anggreni et al., 2017; Suryaningsih et al., 2017). Mind map is a visual thinking tool that illustrates how the various thoughts and information being processed in the human brain and by visualising the thinking process, it could help the users of mind map to understand the way their brain thinks and use words in the mind map for recalling, organising, and problem-solving in their study (LópezBernabé et al., 2020; Mardiah et al., 2019). The integration of a mind map into these two steps can optimise the use of Think-Pair-Share for teaching reading since mind map is a highly adaptive and effective tool for enhancing reading. In the thinking step, students can visualise their understanding and shape their thoughts while thinking about the answer using a mind map, and in the pair step, mind map can be used as a media for discussion.

Several researchers have investigated the integration of mind map and other map-related learning media into Think-Pair-Share. The application of the Mind mapping integrated TPS model affects creativity and student learning outcomes (A. Jatmiko et al., 2018; Oktavia et al., 2016). The findings of previous research also stated 
that a significant effect of the Think-Pair-Share learning model using mind map on senior high school students' learning activities and cognitive learning outcomes (Lubis et al., 2019). Based on the results of the previous studies, it can be concluded that the research about the implementation of Think-Pair-Share integrated with mind map has effectively assisted the students in their learning. Despite these previous studies that have been conducted, there is a lack of study that specifically investigates the effectiveness of online Think-Pair-Share integrated with e-mind map for teaching EFL reading and the current study aimed to fill this gap. Hence, the novelties of this research are the implementation of Think-Pair-Share integrated with mind map for teaching EFL reading and the use of online learning setting to implement the strategy due to this research was carried out during the Covid-19 pandemic, where all teaching-learning activities in the school were conducted in an online learning mode. In this research, online Think-Pair-Share-based reading instruction was assisted with Google Classroom and integrated with the e-mind map using Ayora's e-mind map. Therefore, The purpose of this study was to determine the effectiveness of using e-mind maps in online reading learning based on Think-Pair-Share on the reading comprehension of eleventh graders at SMA Negeri 1 Singaraja.

\section{METHOD}

This study was a pre-experimental study with one-group pretest-posttest design. One-group pretestposttest design is a pre-experimental study that takes one group as the experimental group to be pretested, given the treatment, and administered to the posttest after the treatment. The setting of the study was at SMA Negeri 1 Singaraja, Buleleng Regency, Bali. This school was chosen as the research setting due to it supports the implementation of online learning. The population of this study was eleventh-grade students of SMA Negeri 1 Singaraja in the academic year of 2020/2021, whereas the sample was 32 eleventh-grade students taken from one intact class. XI MIPA 1 was one of the intact classes that the English teacher of the school randomly assigned to be the experimental group of the study. Before the treatment, the group was pretested. The pretest consists of 35 reading comprehension questions in the form of a multiple-choice test. Then, the group was exposed to the treatment under online Think-Pair-Share integrated with e-mind map as the strategy for teaching reading with Analytical Exposition Text as the reading material. The treatment was given four times. After the treatment, a reading comprehension test consisting of 35 questions was administered for the group as the posttest.

Furthermore, the obtained data were analysed using descriptive and inferential statistics assisted with IBM SPSS Statistics version 24. Descriptive statistics were used to analyse the mean and standard deviation of the obtained data. Meanwhile, the inferential statistics using dependent samples t-test (paired-samples test) was administered to measure the significant difference between the mean of the pretest score and the mean of the posttest score and to determine whether the hypothesis of the study was rejected or not. The study used null hypothesis in which there is no significant difference between the mean of pretest score and posttest score in students' reading comprehension before and after the treatment under online Think-Pair-Share integrated with emind map. Before the paired-sample test was conducted, data screening was done using a normality test to ensure the data were normally distributed. The normality test was analysed using Kolmogorov-Smirnov assisted with IBM SPSS Statistics version 24.

\section{RESULT AND DISCUSSION}

\section{Result}

The pretest and posttest scores were analysed using descriptive and inferential statistics assisted with IBM SPSS Statistics version 24. The mean of the pretest score was 75.71, and the mean of the posttest score was 91.12. It shows that the mean of the posttest score was higher than the pretest score. Meanwhile, the standard deviation of the pretest was 9.281, which was higher than the standard deviation of the posttest, which was 7.512. It indicates a significant difference between the mean of students' pretest and post-test scores before and after the treatment. Therefore, it could be assumed that the difference between the mean of the pretest score and posttest score would be significant based on the results of descriptive statistics.

Inferential statistics using paired-samples test was conducted to measure the significant difference between the mean of students' pretest score and posttest score. Before the data were analysed using pairedsamples test, normality test should be done to ensure that the data were normally distributed. The normality test was calculated in IBM SPSS Statistics version 24 using the Kolmogorov Smirnov. The Sig. value from the pretest score was .200, while the Sig. value of the posttest score was .068 . It could be seen that each of the Sig. value had exceeded .05 . The data are normally distributed if the significance value is higher than .05 . Based on these results, it could be concluded that the pretest and posttest data were normally distributed. Since the data were normally distributed, the paired-samples test could be processed using IBM SPSS Statistics version 24. The Sig. (two-tailed) value was .000 , lower than the significant level of .05 . It indicates that the null hypothesis was rejected. There was a significant difference between the mean of pretest score and posttest score in students' 
reading comprehension before and after being taught using online Think-Pair-Share integrated with e-mind map. Hence, it could be concluded that there was an increase in students' reading comprehension from the pretest and posttest after the treatment.

\section{Discussion}

The results of data analysis show that the use of online Think-Pair-Share integrated with e-mind map is proven to be effective in enhancing eleventh-grade students' reading comprehension at SMA Negeri 1 Singaraja. The effectiveness could be proven through the results of students' pretest and posttest scores. The mind map is a highly adaptive and effective tool for enhancing reading (Astawan \& Sudana, 2014; Wibowo et al., 2017). The utilisation of mind map in learning the target language is particularly effective in enhancing reading comprehension among the EFL students (Bystrova \& Larionova, 2015; Fun \& Maskat, 2010). Moreover, the Think-Pair-Share is a flexible, cooperative learning strategy that can be implemented for teaching different grade levels or any content area, including reading (Anggreni et al., 2017; Wulandari, Abadi, \& Ganing, 2018).

Mind maps are becoming more popular, and electronic forms of mind maps are starting to appear. The use of an electronic mind map (e-mind map) is easier and more interesting than the traditional form because it includes images, colors, and images (Andriani et al., 2014; Cemara \& Sudana, 2019). Electronic mind maps can provide a more exciting and effective tool for students to visualise their understanding (Parmin et al., 2015; Sunarman et al., 2015). As already mentioned, the learning process is carried out online due to the Covid-19 pandemic. Think-Pair-Share is assisted by Google Classroom and mind map integration in Think-Pair-Share using e-mind maps to support its implementation in online settings.

Several reasons could be highlighted for why online Think-Pair-Share with e-mind map integration was effective in enhancing students' reading comprehension. For instance, mind map is highly effective for notetaking and reading, mind map could assist the students to understand the ideas through summarising the information into keywords, mind map helps the students to visualise the thinking process, and mind map is an effective tool in processing the information due to it reflects how the human brain works. In addition, ThinkPair-Share is a multi-mode cycle discussion consisting of three different stages of activities, namely think, pair, and share (Dharmayanti et al., 2017; Suryaningsih et al., 2017). Think-Pair-Share is a flexible strategy, and there are various ways for students to do the three steps (Pangestuti, 2017; Wulandari, Abadi, \& Suniasih, 2018). For example, during thinking time, students can write down their ideas on a list or create a visual organiser to build their thinking while thinking about the answer.

The findings of previous studies also stated that Think-Pair-Share could improve the learning atmosphere in students (Dewi et al., 2017; Santra et al., 2018). Other research findings also state that Think-PairShare can make it easier for students to understand the subject matter (Fitriani \& Wuryandari, 2019; J. Jatmiko, 2015). Other research also states that mind maps make it easier for students to learn (Astuti et al., 2013; Liu et al., 2018). Therefore, this study found that integrating e-mind maps in online Think-Pair-Share settings positively and significantly affected students' reading comprehension. This research implies that teachers can use the integration of e-mind maps in online Think-Pair-Share settings to improve students' reading comprehension. Therefore, it could be concluded that using e-mind map in the setting of online Think-Pair-Share is effective for teaching Indonesian EFL students reading. In light of the study results, the researcher recommends conducting further research about the use of e-mind map in online Think-Pair-Share setting in different contexts and skills with different purposes that would contribute to English language teaching.

\section{CONCLUSION}

Based on the data analysis in the results and discussions, students' reading comprehension has increased after being taught using online Think-Pair-Share integrated with the e-mind map as a strategy for teaching reading. It shows a positive and significant effect of e-mind map use on EFL students' reading comprehension in the setting of online Think-Pair-Share.

\section{REFERENCES}

Al-Maroof, R. A. S., \& Al-Emran, M. (2018). Students Acceptance of Google Classroom: An Exploratory Study using PLS-SEM Approach. International Journal of Emerging Technologies in Learning (IJET), 13(06), 112-123. https://doi.org/10.3991/ijet.v13i06.8275

Albashtawi, A. H., \& Al Bataineh, K. B. (2020). The effectiveness of google classroom among EFL students in Jordan: An innovative teaching and learning online platform. International Journal of Emerging Technologies in Learning, 15(11), 78-88. https://doi.org/10.3991/IJET.V15I11.12865 
Ali, M. K., \& Maksum, H. (2020). Utilisation of E-Learning-Based ICT Learning Using the Google Classroom Application During the COVID-19 Pandemic. Journal of Education Research and Evaluation, 4(4), 373. https://doi.org/10.23887/jere.v4i4.29181

Andriani, K., Sudana, D. N., \& Suranata, K. (2014). Pengaruh Model Pembelajaran Savi Bermuatan Peta Pikiran ( Mind Mapping ) Terhadap Hasil Belajar Ipa Pada Siswa Kelas V Sd Semester Ganjil Di Gugus Vi Kecamatan Sawan Kabupaten Buleleng Tahun Pelajaran 2013-2014. Jurnal Mimbar PGSD Universitas Pendidikan Ganesha, 2(1). https://doi.org/10.23887/jjpgsd.v2i1.2287

Anggraeni, S. W., Alpian, Y., Prihamdani, D., \& Nurdini, D. (2021). Analısıs Kesulitan Belajar Membaca Siswa Sekolah Dasar. Jurnal Elementaria Edukasia, 4(1), 42-54. https://doi.org/10.31949/jee.v4i1.2849

Anggreni, P. F., Asri, I. A. S., \& Ganing, N. N. (2017). Pengaruh Model Pembelajaran Kooperatif Tipe ThinkPair-Share ( Tps ) Berbantuan Media Kartu Bergambar Terhadap Penguasaan Kompetensi Pengetahuan Ips Siswa Kelas V Gugus Letkol Wisnu. Mimbar PGSD, 5(2), 1-10. https://doi.org/10.23887/jjpgsd.v5i2.10645

Antara, \& Aditya, P. (2019). Pengaruh Model Pembelajaran Kontekstual Terhadap Kemampuan Membaca Permulaan Anak. Mimbar Ilmu, 24. https://doi.org/10.23887/mi.v24i2.21263

Astawan, I. G., \& Sudana, D. N. (2014). Penerapan Model Pembelajaran SAVI Bermuatan Peta Pikiran untuk Meningkatkan Motivasi dan Hasil Belajar IPA Siswa Kelas V SD. In Sekolah Dasar : Kajian Teori dan Praktik Pendidikan (Vol. 23, Issue 2).

Astuti, N. P. A. W., Ardana, I. K., \& Suardika, I. W. R. (2013). Pengaruh Model Pembelajaran Savi Bermuatan Mind Mapping Terhadap Hasil Belajar IPA Siswa Kelas Iv Sekolah Dasar Gugus III Mengwi. Mimbar PGSD Undiksha, 1(1). https://doi.org/10.23887/jjpgsd.v1i1.1231

Ayuni, D., Marini, T., Fauziddin, M., \& Pahrul, Y. (2021). Kesiapan Guru TK Menghadapi Pembelajaran Daring Masa Pandemi Covid-19. Jurnal Obsesi: Jurnal Pendidikan Anak Usia Dini, 5(1). https://doi.org/10.31004/obsesi.v5i1.579

Bystrova, T., \& Larionova, V. (2015). Use of Virtual Mind Mapping to Effectively Organise the Project Activities of Students at the University. Procedia-Social and Behavioral Sciences, 214. https://doi.org/10.1016/j.sbspro.2015.11.724

Cemara, G. A. G., \& Sudana, D. N. (2019). Pengaruh Model Pembelajaran SAVI Bermuatan Peta Pikiran Terhadap Kreativitas dan Penguasaan Kompetensi Pengetahuan IPA Siswa. Jurnal Ilmiah Sekolah Dasar, 3(3), 359-368. https://doi.org/10.23887/jisd.v3i3.18895

Cici Marantika. (2019). Pengaruh Buku Cerita Bergambar Terhadap Keterampilan Membaca Nyaring Peserta Didik Kelas III Min 7 Bandar Lampung. Jurnal Pendidikan, 78. https://doi.org/10.1017/CBO9781107415324.004

Dashtestani, R. (2013). Implementing mobile-assisted language learning (MALL) in an EFL context: Iranian EFL teachers' perspectives on challenges and affordances. The JALT CALL Journal, 9(2), 149-168. https://doi.org/10.29140/jaltcall.v9n2.153

Dewi, N. P. R. S., Ganing, N. N., \& Suadnyana, I. N. (2017). Pengaruh Model Pembelajaran Kooperatif Tipe Think Pair Share Berbantuan Mind Mapping Terhadap Kompetensi Pengetahuan IPA Siswa Kelas V SD Gugus Kompyang Sujana Denpasar Utara. MIimbar PGSD Undiksha, 5. https://doi.org/10.23887/jjpgsd.v5i2.10623

Dharmayanti, N. P., Ardana, I. K., \& Suniasih, N. W. (2017). Pengaruh Model Pembelajaran Kooperatif Tipe Think Pair Share Berbasis Outdoor Study Terhadap Kompetensi Pengetahuan IPA. Mimbar PGSD, 5, 110. https://doi.org/10.23887/jjpgsd.v5i2.10709

Dwigustini, R., \& Widiya, J. (2020). Think Pair Share Technique to Promote Students' Reading Comprehension. Jurnal Ilmu Pendidikan, 12(1). https://doi.org/10.37640/jip.v12i1.270

Farsani, M. A., Jamali, H. R., Beikmohammadi, M., Ghorbani, B., \& Daneshvar, L. S. (2021). Methodological orientations, academic citations, and scientific collaboration in applied linguistics: What do research synthesis and bibliometrics indicate? System, 100. https://doi.org/10.1016/j.system.2021.102547

Fathiara, A., Badarudin, B., \& Muslim, A. H. (2019). Meningkatkan Keterampilan Berpikir Kritis Dan Gemar Membaca Peserta Didik Melalui Model Predict Observe Explain Berbasis Literasi. Muallimuna: Jurnal Madrasah Ibtidaiyah, 4(2), 92-101. https://doi.org/10.31602/muallimuna.v4i2.1863

Fernández-Gutiérrez, M., Gimenez, G., \& Calero, J. (2020). Is the use of ICT in education leading to higher student outcomes? Analysis from the Spanish Autonomous Communities. Computers and Education, 157, 103969. https://doi.org/10.1016/j.compedu.2020.103969

Fitriani, K., \& Wuryandari, W. (2019). Media Kajian Kewarganegaraan Pengaruh model kooperatif tipe Think Pair Share terhadap kerja sama siswa. Jurnal Civics, 16(1), 80-88. https://doi.org/10.21831/jc.v16i1.21520

Foldnes, N. (2016). The flipped classroom and cooperative learning: Evidence from a randomised experiment. SAGE Journal, 17(1). https://doi.org/10.1177\%2F1469787415616726

Fun, C. S., \& Maskat, N. (2010). Teacher-Centered Mind Mapping vs Student-Centered Mind Mapping in the 
Teaching of Accounting at Pre-U Level - An Action Research. International Conference on Learner Diversity, 240. https://doi.org/10.1016/j.sbspro.2010.10.034

Guswara, A. M. (2020). The Contribution of Google Classroom Application and Motivation to The Learning Outcomes of Web Programming. Educational Technology, 4(4), 1-9. https://doi.org/10.23887/jet.v4i4.29896

Hanik, E. U. (2020). Self directed learning berbasis literasi digital pada masa pandemi covid-19 di Madrasah Ibtidaiyah. $\quad$ ELEMENTARY: Islamic Teacher $\quad$ Journal, $\quad 8(1), \quad 183$. https://doi.org/10.21043/elementary.v8i1.7417

Hwang, G. J., Wang, S. Y., \& Lai, C. L. (2020). Effects of a social regulation-based online learning framework on students' learning achievements and behaviors in mathematics. Computers and Education, 160, 104031. https://doi.org/10.1016/j.compedu.2020.104031

Jatmiko, A., Kartina, Y., Irwandani, I., Fakhri, J., Pricilia, A., \& Rahayu, T. (2018). Reading Concept MapThink Pair Share (Remap-TPS) Learning Model on Cognitive Ability and Scientific Attitude. Jurnal Keguruan Dan Ilmu Tarbiyah, 3(2). https://doi.org/10.24042/tadris.v3i2.3184

Jatmiko, J. (2015). Eksperimen Model Pembelajaran Think-Pair-Share Dengan Modul(Tps-M) Terhadap Prestasi Belajar Matematika Ditinjau Dari Minat Belajar. JIPM (Jurnal Ilmiah Pendidikan Matematika), 3(2), 417426. https://doi.org/10.25273/jipm.v3i2.511

Kamelia, K. (2019). Using Video as Media of Teaching in English Language Classroom: Expressing Congratulation and Hopes. Utamax : Journal of Ultimate Research and Trends in Education, 1(1), 34-38. https://doi.org/10.31849/utamax.v1i1.2742

Knoop-van Campen, C. A. N., Segers, E., \& Verhoeven, L. (2020). Effects of audio support on multimedia learning processes and outcomes in students with dyslexia. Computers and Education, 150(February), 103858. https://doi.org/10.1016/j.compedu.2020.103858

Kurniawan, Elmunsya, \& Muladi. (2018). Perbandingan Penerapan Model Pembelajaran Project Based Learning (PJBL) dan Think Pair Share (TPS) Berbantuan Modul Ajar Terhadap Kemandirian dan Hasil Belajar Rancang Bangun. Jaringan JP (Jurnal Pendidikan), 3(2). https://doi.org/10.26740/jp.v3n2.p80-85

Liebech-Lien, B. (2021). Teacher teams - A support or a barrier to practising cooperative learning? Teaching and Teacher Education, 106. https://doi.org/10.1016/j.tate.2021.103453

Liu, Y., Tong, Y., \& Yang, Y. (2018). The Application of Mind Mapping into College Computer Programming Teaching. Procedia Computer Science, 129. https://doi.org/https://doi.org/10.1016/j.procs.2018.03.047

López-Bernabé, E., Foudi, S., \& Galarraga, I. (2020). Mind the map? Mapping the academic, citizen and professional stakeholder views on buildings and heating behaviour in Spain. Energy Research \& Social Science, 69. https://doi.org/10.1016/j.erss.2020.101587

Lubis, R., Herlina, M., \& Rukmana, J. (2019). Pengaruh Model Pembelajaran Think Pair Share Menggunakan Media Mind Mapping terhadap Aktivitas dan Hasil Belajar Kognitif Siswa. BIOEDUSAINS: Jurnal Pendidikan Biologi Dan Sains, 2(2). https://doi.org/10.31539/bioedusains.v2i2.978

Mahitsa, M., \& Mahardini, A. (2020). Analisis Situasi Penggunaan Google Classroom pada Pembelajaran Daring Fisika. Jurnal Pendidikan FIsika, VIII(2), 215-224. https://doi.org/10.24127/jpf.v8i2.3102 ANALISIS

Mardiah, M., Hendra, H., \& Hastina, N. (2019). Aplikasi Edraw Mind Map Bagi Guru Sd Negeri 050702 Kecamatan Secanggang Kabupaten Langkat. Jurnal Pengabdian Kepada Masyarakat, 2(2). https://doi.org/10.31604/jpm.v2i2.71-77

Oktavia, R., Mustikaningtyas, D., \& Mubarok, I. (2016). Pengaruh Model Think-Pair-Share (Tps) Terintegrasi Mind Mapping Terhadap Kreativitas Dan Hasil Belajar Siswa. Journal of Biology Education, 5(2). https://doi.org/10.15294/jbe.v5i2.14656

Pangestuti, A. A. (2017). Penerapan Model Pembelajaran Think Pair Share ( Tps ) Berbasis Lesson Study Untuk Meningkatkan Keterampilan Sosial Dan Hasil Belajar Kognitif Mahasiswa. Jurnal Penelitian Pendidikan Biologi, 1(2), 135-142. https://doi.org/10.32502/dikbio.v1i2.782

Parmin, Sajidan, Ashadi, \& Sutikno. (2015). Skill of prospective teacher in integrating the concept of science with local wisdom model. Jurnal Pendidikan IPA Indonesia, 4(2), 120-126. https://doi.org/10.15294/jpii.v4i2.4179

Pramesti, F. (2018). Analisis Faktor-Faktor Penghambat Membaca Permulaan pada Siswa Kelas 1 SD. Jurnal Ilmiah Sekolah Dasar, 2(3), 283-289. https://doi.org/10.23887/jisd.v2i3.16144

Rabgay, T. (2018). The effect of using cooperative learning method on tenth grade students' learning achievement and attitude towards biology. International Journal of Instruction, 11(2), 265-280. https://doi.org/10.12973/iji.2018.11218a

Raynesa Noor Emiliasari. (2019). Lesson Planning in EFL Classroom: A Case Study in Lesson Plan Preparation and Implementation. Wiralodra English Journal, 3(2), 367-375. https://doi.org/10.31943/wej.v3i2.67 
Santosa, F. H., Negara, H. R. P., \& Samsul Bahri. (2020). Efektivitas Pembelajaran Google Classroom Terhadap Kemampuan Penalaran Matematis Siswa. Jurnal Pemikiran Dan Penelitian Pendidikan Matematika (JP3M), 3(1), 62-70. https://doi.org/10.36765/jp3m.v3i1.254

Santra, Putu, Citra Wibawa, I. M., \& Rati, N. W. (2018). Pengaruh Model Pembelajaran Think Pair Share Berbantuan Power Point Terhadap Hasil Belajar Ipa. Jurnal Imiah Pendidikan Dan Pembelajaran, 2(1), 307-315. https://doi.org/10.23887/jipp.v2i1.13975

Shaalan, I. E.-N. A. W. (2019). Remodeling teachers' and students' roles in self-directed learning. Journal of Language Teaching and Research, 10(3), 549-556. https://doi.org/10.17507/jltr.1003.19

Shastina, E. M., Jentgens, S., Shatunova, O. V., Borisov, A. M., \& Bozhkova, G. N. (2020). Role of literary pedagogy in modern education of preschool and primary school children. Space and Culture, 8(1), 234243. https://doi.org/10.20896/saci.v8i1.795

Shih, Y.-C., \& Reynols, B. L. (2015). Teaching Adolescents EFL by Integrating Think-Pair-Share and Reading Strategy Instruction: A Quasi-Experimental Study. RELC Journal, 6(1). https://doi.org/10.1177/0033688215589886

Sunarman, I. P. A., Suniasih, N. W., \& Putra, M. (2015). Model Pembelajaran Mind Mapping Berpengaruh Terhadap Hasil Belajar Matematika Siswa Kelas V Sd Gugus 2 Luwus Mekarsari. MIMBAR PGSD Undiksha, 3(1). https://doi.org/10.23887/jjpgsd.v3i1.4841

Suryaningsih, N. K. E., Putra, D. K. N. S., \& Negara, I. G. A. O. (2017). Pengaruh Model Pembelajaran Kooperatif Tipe Think Pair Share (TPS) Terhadap Penguasaan Kompetensi Pengetahuan Ipa Siswa Kelas Iv Sd Gugus Untung Surapati Denpasar Tahun Ajaran 2016/2017. MIMBAR PGSD Undiksha, 5(2). https://doi.org/10.23887/jjpgsd.v5i2.10784

Troussas, C., Krouska, A., \& Sgouropoulou, C. (2020). Collaboration and fuzzy-modeled personalisation for mobile game-based learning in higher education. Computers \& Education, 144. https://doi.org/10.1016/j.compedu.2019.103698

Wibowo, R., Widiati, U., \& Santoso, A. (2017). Bahan Ajar Tematik Materi Puisi Kelas V SD dengan Pemanfaatan Peta Pikiran dan Lingkungan sekitar. Jurnal Pendidikan: Teori, Penelitian, Dan Pengembangan, 2(6), 743-750. https://doi.org/10.17977/jptpp.v2i6.9324

Widyaningrum, H. K., \& Hasanudin, C. (2019). Kajian Kesulitan Belajar Membaca Menulis Permulaan (MMP) di Sekolah Dasar [Study of Difficulty Learning to Read Beginning Writing (MMP) in Primary School]. Pedagogia: Jurnal Pendidikan, 8(2), 189-200. https://doi.org/10.21070/pedagogia.v8i2.2219

Widyowati, F. T., Rahmawati, I., \& Priyanto, W. (2020). Pengembangan Media Pembelajaran Membaca Mengeja Berbasis Aplikasi untuk Kelas 1 Sekolah Dasar. International Journal of Community Service Learning, 4(4), 332-337. https://doi.org/10.23887/ijcsl.v4i4

Windrawati, W., Solehun, \& Gafur, H. (2020). Analisis Faktor Penghambat Belajar Membaca Permulaan pada Siswa Kelas 1 SD Inpres 141 Matalamagi Kota Sorong. Jurnal Papeda, 2(1), 10-16. https://doi.org/10.36232/jurnalpendidikandasar.v2i1.405

Wulandari, P., Abadi, I. B. G. S., \& Ganing, N. N. (2018). Pengaruh Model Pembelajaran Think Pair Share Berbasis Penilaian Portofolio Terhadap Kompetensi Pengetahuan Ipa Siswa Kelas Iv Sd Negeri Gugus Kapten Kompyang Sujana Denpasar Barat Tahun 2017/2018. Mimbar PGSD, 6, 1-9. https://doi.org/10.23887/jjpgsd.v6i3.15772

Wulandari, P., Abadi, I. B. G., \& Suniasih, N. W. (2018). Pengaruh Model Pembelajaran Think Pair Share Berbasis Penilaian Portofolio Terhadap Kompetensi Pengetahuan IPA Siswa Kelas IV SS Negeri Gugus Kapten Kompyang Sujana Denpasar Barat Tahun 2017/2018. MIMBAR PGSD Undiksha, 6(3), 161-168. https://doi.org/10.23887/jjpgsd.v6i3.15772

YalÇintaŞ Sezgin, E., \& Ulus, L. (2017). The early literacy at preschool education: The book or the E-book? Turkish Online Journal of Educational Technology, 16(4), 77-83.

Yati, W., \& Amini, R. (2020). Pengembangan Bahan Ajar Dengan Pendekatan Cooperative Learning Tipe Turnamen Pada Siswa Kelas IV SD. Jurnal Basicedu, 4(1), 158-167. https://doi.org/10.31004/basicedu.v4i1.335

Zabolotniaia, M., Cheng, Z., Dorozhkin, E., \& Lyzhin, A. (2020). Use of the LMS Moodle for an Effective Implementation of an Innovative Policy in Higher Educational Institutions. International Journal of Emerging Technologies in Learning (IJET), 15(13), 172. https://doi.org/10.3991/ijet.v15i13.14945

Zhang, Y., Ghandour, A., \& Shestak, V. (2020). Using Learning Analytics to Predict Students Performance in Moodle LMS. International Journal of Emerging Technologies in Learning. https://doi.org/10.3991/ijet.v15i20.15915 